\title{
TABLE OF CONTENTS VOLUME 43
}

\section{ANNOUNCEMENT}

The 2020 Albert Valdman Award

\section{INTRODUCTION}

Gass, Susan. Editor's Message

\section{RESEARCH ARTICLES}

BAÑÓN, JOSÉ ALEMÁN, MILLER, DAVID, AND ROTHMAN, JASON. Examining the Contribution of Markedness to the L2 Processing of Spanish Person Agreement: An Event Related Potentials Study

BOERS, FRANK, BRYFONSKI, LARA, FAEZ, FARAHNAZ, AND MCKAY, TODD. A Call for Cautious Interpretation of Meta-Analytic Reviews

CHO, CHRISTINE MOONKYOUNG, AND DEWAELE, JEAN-MARC. A Crosslinguistic Study of the Perception of Emotional Intonation: Influence of the Pitch Modulations

CHO, MINYOUNG. Regulatory Fit Effects on the Acquisition of Lexical Stress: A Classroom-Based Study

CINTRÓN-VALENTÍN, MYRNA C., AND GARCÍA-AMAYA, LORENZO. Investigating Textual Enhancement and Captions in L2 Grammar and Vocabulary: An Experimental Study FOLTZ, ANOUSCHKA. Using Prosody to Predict Upcoming Referents in the L1 and the L2: The Role of Recent Exposure 
FOUZ-GONZÁLEZ, JONÁS, AND MOMPEAN, JOSE A.

Exploring the Potential of Phonetic Symbols and Keywords as

Labels for Perceptual Training

$297-328$

FU, MENGXIA, AND LI, SHAOFENG. The Associations Between

Implicit and Explicit Language Aptitude and the Effects of the

Timing of Corrective Feedback

$498-522$

GAO, JIANWU, AND MA, SHUANG. Learning Condition,

Linguistic Complexity, and First Language Transfer in Semiartificial

Language Learning: A Conceptual Replication and Extension of

Tagarelli et al. (2016)

$355-378$

GE, HAOYAN, CHEN, AOJU, AND YIP, VIRGINIA. Comprehension

of Focus-to-Accentuation Mapping in Sentences with Only

by Advanced Cantonese Learners and Dutch Learners of English

$25-49$

GOAD, HEATHER, GUZZO, NATÁLIA BRAMBATTI, AND

WHITE, LYDIA. Parsing Ambiguous Relative Clauses in L2

English: Learner Sensitivity to Prosodic Cues

83-108

GODFROID, ALINE, AND KIM, KATHY MINHYE. The

Contributions of Implicit-Statistical Learning Aptitude to Implicit

Second-Language Knowledge

$606-634$

HURTADO, IRATI, AND MONTRUL, SILVINA. Priming Dative

Clitics in Spoken Spanish as a Second and Heritage Language

$729-752$

KHAJAVY, GHOLAM HASSAN, MACINTYRE, PETER D., AND HARIRI, JAMAL. A Closer Look at Grit and Language

Mindset as Predictors of Foreign Language Achievement

KIM, HYUNWOO, AND GRÜTER, THERES. Predictive Processing

of Implicit Causality in a Second Language: A Visual-World

Eye-Tracking Study

KYLE, KRISTOPHER, CROSSLEY, SCOTT, AND VERSPOOR,

MARJOLIJN. Measuring Longitudinal Writing Development

Using Indices of Syntactic Complexity and Sophistication

$781-812$

LEWANDOWSKI, WOJCIECH, AND ÖZÇALIŞKAN, ŞEYDA.

The Specificity of Event Expression in First Language Influences

Expression of Object Placement Events in Second Language

838-869

LI, SHAOFENG, AND QIAN, JIANCHENG. Exploring Syntactic

Priming as a Measure of Implicit Language Aptitude

LINDSTROMBERG, SETH AND EYCKMANS, JUNE.

The Retrievability of L2 English Multiword Items in a Context

of Strongly Form-Focused Exposure: What Matters?

1040-1067

LINFORD, BRET, HARLEY, ALICIA, AND BROWN, EARL K.

Second Language Acquisition of /S/-Weakening in a Study

Abroad Context

$403-427$

MAJUDDIN, ELVENNA, SIYANOVA-CHANTURIA, ANNA, AND BOERS, FRANK. Incidental Acquisition of Multiword Expressions Through Audiovisual Materials: The Role of Repetition and Typographic Enhancement 
MARX, NICOLE, GILL, CHRISTIAN, AND BROSOWSKI, TIM. Are Migrant Students Closing the Gap? Reading Progression in the First Years of Mainstream Education

PELZL, ERIC, LAU, ELLEN F., GUO, TAOMEI, AND DEKEYSER, ROBERT. Even in the Best-Case Scenario L2 Learners Have Persistent Difficulty Perceiving and Utilizing Tones in Mandarin: Findings from Behavioral and Event-Related Potentials Experiments

POZZI, REBECCA, AND BAYLEY, ROBERT. The Development of a Regional Phonological Feature During a Semester Abroad in Argentina

SUN, HUI, SAITO, KAZUYA, AND TIERNEY, ADAM. A Longitudinal Investigation of Explicit and Implicit Auditory Processing in L2 Segmental and Suprasegmental Acquisition

TERAI, MASATO, YAMASHITA, JUNKO, AND PASICH, KELLY E. Effects of Learning Direction in Retrieval Practice on EFL Vocabulary Learning

VANDENBERGHE, BERT, PEREZ, MARIBEL MONTERO, REYNVOET, BERT, AND DESMET, PIET. Combining Explicit and Sensitive Indices for Measuring L2 Vocabulary Learning Through Contextualized input and Word-Focused Instruction 1009-1039 WIENER, SETH, ITO, KIWAKO, AND SPEER, SHARI R. Effects of Multitalker Input and Instructional Method on the DimensionBased Statistical Learning of Syllable-Tone Combinations: An Eye-Tracking Study

YILMAZ, YUCEL, AND GRANENA, GISELA. Implicitness and Explicitness in Cognitive Abilities and Corrective Feedback: A Double Dissociation?

YU, XIAORU, JANSE, ESTHER, AND SCHOONEN, ROB. The Effect of Learning Context on L2 Listening Development: Knowledge and Processing

ZALBIDEA, JANIRE. On the Scope of Output in SLA: Task Modality, Salience, L2 Grammar Noticing, and Development $50-82$ ZALBIDEA, JANIRE, ISSA, BERNARD I., FARETTA-STUTENBERG, MANDY, AND SANZ, CRISTINA. Initial Proficiency and L2 Grammar Development During Short-Term Immersion Abroad: Conceptual and Methodological Insights

\section{RESEARCH REPORTS}

LIPSKI, JOHN M. Language Revitalization as L2 Shadow Boxing: The Case of Palenquero Plural-Marking 220-235

NAKAMURA, SACHIKO, PHUNG, LINH, AND REINDERS, HAYO. The Effect of Learner Choice on L2 Task Engagement 
SUZUKI, YUICHI. Probing the Construct Validity of LLAMA_D as a Measure of Implicit Learning Aptitude: Incidental Instructions, Confidence Ratings, and Reaction Time

TAFT, MARCUS, AND LI, JUNMIN. A New Type of Masked form Priming: Native Versus Nonnative English Speakers

ZHANG, JIE, LI, HONG, AND LIU, YANG. The Influence of Orthography on Oral Vocabulary Acquisition in Learners of Chinese as a Second Language

\section{REPLICATION STUDIES}

LOZANO-ARGÜELLES, CRISTINA, ARROYO, LAURA FERNÁNDEZ, RODRÍGUEZ, NICOLE, LÓPEZ, EZEQUIEL M. DURAND, POZÚ, JUAN J. GARRIDO, MARKOVITS, JENNIFER, VARELA, JESSICA P., DE ROCAFIGUERA, NÚRIA, AND CASILLAS, JOSEPH V. Conceptually Cued Perceptual Categorization in Adult L2 Learners

ROGERS, JOHN, AND CHEUNG, ANISA. Does it Matter When you Review? Input Spacing, Ecological Validity, and the Learning of L2 Vocabulary

\section{CRITICAL COMMENTARIES}

BROWN, DALE, STEWART, JEFFREY, STOECKEL, TIM, AND MCLEAN, STUART. The Coming Paradigm Shift in the Use of Lexical Units

$950-953$

DANG, THI NGOC YEN. Selecting Lexical Units in Wordlists for EFL Learners

954-957

DEKEYSER, ROBERT, AND LI, SHAOFENG. Epilogue: Evidence for the Validity of Implicit Aptitude and the Need for Construct Validation

GABLASOVA, DANA, AND BREZINA, VACLAV. Words that Matter in L2 Research and Pedagogy: A Corpus-Linguistics Perspective

KREMMEL, BENJAMIN. Selling the (Word) Family Silver? A Response to Webb's "Lemma Dilemma"

LAUFER, BATIA. Lemmas, Flemmas, Word Families, and Common Sense

NATION, PAUL. Thoughts on Word Families

PERRUCHET, PIERRE. Why is the Componential Construct of 969-972 Implicit Language Aptitude So Difficult to Capture?

A Commentary on the Special Issue 
STEWART, JEFFREY, STOECKEL, TIM, MCLEAN, STUART, NATION, PAUL, AND PINCHBECK, GEOFFREY G. What the Research Shows about Written Receptive Vocabulary Testing: A Reply to Webb

WEBB, STUART. A Different Perspective on the Limitations of Size and Levels Tests of Written Receptive Vocabulary Knowledge

WEBB, STUART. The Lemma Dilemma: How Should Words be Operationalized in Research and Pedagogy?

WEBB, STUART. Word Families and Lemmas, Not A Real Dilemma: Investigating Lexical Units

\section{METHODS FORUM}

BUFFINGTON, JOSHUA, DEMOS, ALEXANDER P., AND MORGAN-SHORT, KARA. The Reliability and Validity of Procedural Memory Assessments Used in Second Language Acquisition Research

NAGLE, CHARLES L., AND REHMAN, IVANA. Doing L2 Speech Research Online: Why and How to Collect Online Ratings Data

NOROUZIAN, REZA. Interrater Reliability in Second Language Meta-Analyses: The Case of Categorical Moderators

\section{CORRIGENDUM/ERRATUM}

POZZI, REBECCA, AND BAYLEY, ROBERT. The Development of a Regional Phonological Feature During a Semester Abroad in Argentina - Corrigendum

TERAI, MASATO, YAMASHITA, JUNKO, AND PASICH, KELLY E. Effects of Learning Direction in Retrieval Practice on EFL Vocabulary Learning - Erratum

\section{STATE OF THE SCHOLARSHIP}

LI, SHAOFENG, AND DEKEYSER, ROBERT. Implicit Language Aptitude: Conceptualizing the Construct, Validating the Measures, and Examining the Evidence: Introduction to the Special Issue 

${ }_{\text {POSTAL SERVICE }}$ (All Periodicals Publications Except Requester Publications)

Studies in Second Language Acquisition

4. Issue Frequency

Mar, May, July, Sep, Dec

$$
010-955
$$

5. Number of Issues Published Annually 5

7. Complete Mailing Address of Known Office of Publication (Not printer) (Street, city, county, state, and ZIP+4®)

Cambridge University Press

1 Liberty Plaza

New York, NY 10006

8. Complete Mailing Address of Headquarters or General Business Office of Publisher (Not printer)

\section{Cambridge University Press}

Edinburgh Building, Cambridge CB2 2RU, England
3. Filing Date

$10 / 1 / 2021$

6. Annual Subscription Price $\$ 666$

Contact Person

NINA IAMMATTEO

Telephone (Include area code) 2123375004

9. Full Names and Complete Mailing Addresses of Publisher, Editor, and Managing Editor (Do not leave blank)

Publisher (Name and complete mailing address)

Cambridge University Press

1 Liberty Plaza

New York, NY 10006

Editor (Name and complete mailing address)

Susan Gass, B 230 Wells Hall, 619 Red Cedar Road, Michigan State University, E. Lansing, MI 48824, USA

Managing Editor (Name and complete mailing address)

10. Owner (Do not leave blank. If the publication is owned by a corporation, give the name and address of the corporation immediately followed by the names and addresses of all stockholders owning or holding 1 percent or more of the total amount of stock. If not owned by a corporation, give the names and addresses of the individual owners. If owned by a partnership or other unincorporated firm, give its name and address as well as those of each individual owner. If the publication is published by a nonprofit organization, give its name and address.)

\begin{tabular}{l|l}
\hline Full Name & Complete Mailing Address \\
\hline Cambridge University Press & Edinburgh Building \\
\hline & Shaftesbury Rd \\
\hline & Cambridge CB2 2RU, England \\
\hline
\end{tabular}

11. Known Bondholders, Mortgagees, and Other Security Holders Owning or Holding 1 Percent or More of Total Amount of Bonds, Mortgages, or Other Securities. If none, check box Х None

\begin{tabular}{l|l}
\hline Full Name & Complete Mailing Address \\
\hline & \\
\hline & \\
\hline & \\
\hline
\end{tabular}

12. Tax Status (For completion by nonprofit organizations authorized to mail at nonprofit rates) (Check one)

The purpose, function, and nonprofit status of this organization and the exempt status for federal income tax purposes:

$\square$ Has Not Changed During Preceding 12 Months

$\square$ Has Changed During Preceding 12 Months (Publisher must submit explanation of change with this statement) 


\begin{tabular}{|c|c|c|c|c|}
\hline \multicolumn{3}{|l|}{ 13. Publication Title } & \multicolumn{2}{|c|}{ 14. Issue Date for Circulation Data Below } \\
\hline \multicolumn{3}{|c|}{ Studies in Second Language Acquisition } & \multicolumn{2}{|l|}{ MAY 2021} \\
\hline \multicolumn{3}{|c|}{ 15. Extent and Nature of Circulation } & $\begin{array}{l}\text { Average No. Copies } \\
\text { Each Issue During } \\
\text { Preceding } 12 \text { Months }\end{array}$ & $\begin{array}{l}\text { No. Copies of Single } \\
\text { Issue Published } \\
\text { Nearest to Filing Date }\end{array}$ \\
\hline \multicolumn{3}{|c|}{ a. Total Number of Copies (Net press run) } & 264 & 235 \\
\hline \multirow{4}{*}{$\begin{array}{l}\text { b. Paid } \\
\text { Circulation } \\
\text { (By Mail } \\
\text { and } \\
\text { Outside } \\
\text { the Mail) }\end{array}$} & (1) & $\begin{array}{l}\text { Mailed Outside-County Paid Subscriptions Stated on PS Form } 3541 \text { (Include paid } \\
\text { distribution above nominal rate, advertiser's proof copies, and exchange copies) }\end{array}$ & 45 & 35 \\
\hline & (2) & $\begin{array}{l}\text { Mailed In-County Paid Subscriptions Stated on PS Form } 3541 \text { (Include paid } \\
\text { distribution above nominal rate, advertiser's proof copies, and exchange copies) }\end{array}$ & 0 & 0 \\
\hline & (3) & $\begin{array}{l}\text { Paid Distribution Outside the Mails Including Sales Through Dealers and Carriers, } \\
\text { Street Vendors, Counter Sales, and Other Paid Distribution Outside USPS }{ }^{\circledR}\end{array}$ & 158 & 147 \\
\hline & (4) & $\begin{array}{l}\text { Paid Distribution by Other Classes of Mail Through the USPS } \\
\left.\text { (e.g., First-Class Mail }{ }^{\circledR}\right)\end{array}$ & 0 & 0 \\
\hline \multicolumn{3}{|c|}{ c. Total Paid Distribution [Sum of 15b (1), (2), (3), and (4)] } & 203 & 182 \\
\hline \multirow{4}{*}{$\begin{array}{l}\text { d. Free or } \\
\text { Nominal } \\
\text { Rate } \\
\text { Distribution } \\
\text { (By Mail } \\
\text { and } \\
\text { Outside } \\
\text { the Mail) }\end{array}$} & (1) & Free or Nominal Rate Outside-County Copies included on PS Form 3541 & 0 & 0 \\
\hline & (2) & Free or Nominal Rate In-County Copies Included on PS Form 3541 & 0 & 0 \\
\hline & (3) & $\begin{array}{l}\text { Free or Nominal Rate Copies Mailed at Other Classes Through the USPS } \\
\text { (e.g., First-Class Mail) }\end{array}$ & 0 & 0 \\
\hline & (4) & Free or Nominal Rate Distribution Outside the Mail (Carriers or other means) & 0 & 0 \\
\hline \multicolumn{3}{|c|}{ e. Total Free or Nominal Rate Distribution (Sum of 15d (1), (2), (3) and (4)) } & 0 & 0 \\
\hline \multicolumn{3}{|c|}{ f. Total Distribution (Sum of $15 c$ and $15 e$ ) } & 203 & 182 \\
\hline \multicolumn{3}{|c|}{ g. Copies not Distributed (See Instructions to Publishers \#4 (page \#3)) } & 61 & 53 \\
\hline \multicolumn{3}{|c|}{ h. Total (Sum of $15 f$ and g) } & 264 & 235 \\
\hline \multicolumn{3}{|c|}{$\begin{array}{l}\text { i. Percent Paid } \\
\text { (15c divided by } 15 f \text { times } 100)\end{array}$} & $100 \%$ & $100 \%$ \\
\hline
\end{tabular}

* If you are claiming electronic copies, go to line 16 on page 3. If you are not claiming electronic copies, skip to line 17 on page 3. 
a. Paid Electronic Copies

b. Total Paid Print Copies (Line 15c) + Paid Electronic Copies (Line 16a)

c. Total Print Distribution (Line 15f) + Paid Electronic Copies (Line 16a)

d. Percent Paid (Both Print \& Electronic Copies) (16b divided by $16 \mathrm{c} \times 100$ )

$\square$ I certify that $50 \%$ of all my distributed copies (electronic and print) are paid above a nominal price.

\section{Publication of Statement of Ownership}

\If the publication is a general publication, publication of this statement is required. Will be printed

in the December issue of this publication

18. Signature and Title of Editor, Publisher, Business Manager, or Owner

Nina lammatteo

$10 / 1 / 2021$

I certify that all information furnished on this form is true and complete. I understand that anyone who furnishes false or misleading information on this form or who omits material or information requested on the form may be subject to criminal sanctions (including fines and imprisonment) and/or civil sanctions (including civil penalties). 


\section{STUDIES IN SECOND LANGUAGE ACQUISITION}

\section{Information for Contributors}

For guidelines and requirements regarding manuscript submission, please consult the SSLA website at http://journals.cambridge.org/sla. Click on the Journal Information tab which will lead you to Information for Contributors. Potential authors are advised that all manuscripts are internally reviewed for both content and formatting/style in order to determine their suitability for external evaluation.

Research Article. These manuscripts may be essays or empirical studies, either of which must be motivated by current theoretical issues in second and subsequent language acquisition or heritage language acquisition, including methodological issues in research design and issues related to the context of learning. Maximum length is 11,000 words all-inclusive (i.e., abstract, text, tables, figures, references, notes, and appendices intended for publication must all fall within the 11,000 word limit).

Research Report. These manuscripts are shorter empirical studies motivated by current theoretical issues in second and subsequent language acquisition or heritage language acquisition, including methodological issues in research design. Very often, these are narrowly focused studies or they present part of the results of a larger project in progress. The background and motivation sections are generally shorter than research articles. Maximum length is 6,000 words all-inclusive (i.e., abstract, text, tables, figures, references, notes, and appendices intended for publication must all fall within the 6,000 word limit).

Replication Study. These manuscripts are shorter empirical studies motivated by a previously published study (not necessarily one published in SSLA). The background and motivation sections will necessarily be shorter compared to research articles as the maximum length is 6,000 words all-inclusive (i.e., abstract, text, tables, figures, references, notes, and appendices intended for publication must all fall within the 6,000 word limit).

State-of-the-Scholarship Article. These manuscripts are essays that review the extant research on a particular theme or theoretical issue, offering a summary of findings and making critical observations on the research to date. Manuscripts in this category typically fall within the 11,000-word limit; however, longer manuscripts may be considered on a case-by-case basis.

Critical Commentary. These manuscripts are shorter essays (i.e., non-empirical) motivated by current theory and issues in second and subsequent language acquisition or heritage language acquisition, including methodological issues in research design and issues related to the context of learning. Maximum length is 6,000 words all-inclusive (i.e., abstract, text, tables, figures, references, notes, and appendices intended for publication must all fall within the 6,000 word limit).

Methods Forum. Recognizing the need to discuss and advance SLA research methods, these manuscripts seek to advance methodological understanding, training, and practices in the field. Submissions can be conceptual or empirical; we also encourage articles introducing novel techniques. All research paradigms, epistemologies, ontologies, and theoretical frameworks relevant to SLA are welcome. The target length is up to 11,000 words, although longer manuscripts will be considered with justification.

All manuscripts in all categories are peer reviewed and subject to the same high standards for publication in SSLA. 


\section{Studies in Second Language Acquisition Volume 43 Number 5 December 2021}

\section{CRITICAL COMMENTARIES}

The Lemma Dilemma: How Should Words Be Operationalized in Research and Pedagogy? Stuart Webb

The Coming Paradigm Shift in the Use of Lexical Units

Dale Brown, Jeffrey Stewart, Tim Stoeckel, and Stuart McLean

$950-953$

Selecting Lexical Units in Wordlists for EFL Learners

Thi Ngoc Yen Dang

Words that Matter in L2 Research and Pedagogy: A Corpus-Linguistics Perspective Dana Gablasova and Vaclav Brezina

Selling the (Word) Family Silver? A Response to Webb's "Lemma Dilemma" Benjamin Kremmel

Lemmas, Flemmas, Word Families, and Common Sense Batia Laufer

Thoughts on Word Families Paul Nation

Word Families and Lemmas, Not a Real Dilemma: Investigating Lexical Units Stuart Webb

\section{RESEARCH ARTICLES}

Incidental Acquisition of Multiword Expressions Through Audiovisual Materials:

The Role of Repetition and Typographic Enhancement

Elvenna Majuddin, Anna Siyanova-Chanturia, and Frank Boers

Combining Explicit and Sensitive Indices for Measuring L2 Vocabulary Learning

Through Contextualized Input and Word-Focused Instruction Bert Vandenberghe, Maribel Montero Perez, Bert Reynvoet, and Piet Desmet

1009-1039

The Retrievability of L2 English Multiword Items in a Context of Strongly

Form-Focused Exposure: What Matters?

Seth Lindstromberg and June Eyckmans

Investigating Textual Enhancement and Captions in L2 Grammar and Vocabulary:

An Experimental Study

Myrna C. Cintrón-Valentín and Lorenzo García-Amaya

Regulatory Fit Effects on the Acquisition of Lexical Stress: A Classroom-Based Study Minyoung Cho

Effects of Learning Direction in Retrieval Practice on EFL Vocabulary Learning Masato Terai, Junko Yamashita, and Kelly E. Pasich

\section{REPLICATION STUDY}

Does it Matter When you Review? Input Spacing, Ecological Validity, and the

Learning of L2 Vocabulary

John Rogers and Anisa Cheung

\section{RESEARCH REPORT}

The Influence of Orthography on Oral Vocabulary Acquisition in Learners of Chinese as a Second Language

Jie Zhang, Hong Li, and Yang Liu

\section{ERRATUM}

Effects of Learning Direction in Retrieval Practice on EFL Vocabulary Learning - Erratum

Masato Terai, Junko Yamashita, and Kelly E. Pasich 